\title{
Effect of morning and evening milking interval on chemical quality of milk of Murrah breed
}

\author{
RAVI KARAN AND U.K. SHUKLA
}

\begin{abstract}
A study was conducted at Chitrakoot-Satna (M.P.) and Smriti Products (Pvt.) Ltd., Saha, Ambala (Haryana), during April to June 2014 to evaluate the chemical quality of raw milk of Murrah breed. The objective was to find out the compositional quality of raw milk of Murrah breed, and to find out the effect of morning and evening milking on compositional quality of raw milk. All sanitary precautions were followed to produce clean milk. The samples of raw milk collected for ten days, were tested to determine the percentage of fat, protein, lactose, ash, total solid, water, solid not fat (SNF); and specific gravity. The data obtained for the aforesaid tests were subjected to statistical analysis. The results of the statistical analysis showed that the differences in percentage of fat, protein, ash, total sugar and water in the raw milk of Murrah breed were significant and the results of F-test were also found significant. The differences in percentage of lactose and SNF; and specific gravity were, however, non-significant. It was, therefore, concluded that effect of morning and evening milking interval on chemical quality of milk of Murrah breed was significantly influenced. Morning milk was better than evening milk.
\end{abstract}

KEY WORDS : Morning and evening milking, Chemical quality, Murrah breed

How TO CITE THIS PAPER : Karan, Ravi and Shukla, U.K. (2014). Effect of morning and evening milking interval on chemical quality of milk of Murrah breed. Res. J. Animal Hus. \& Dairy Sci., 5(2) : 159-160. 